\title{
Effects of Calf Removal at Parturition on Postpartum Ovarian Activity in Zebu (Bos indicus) Cows in the Humid Tropics
}

\author{
By R. E. Toribio ${ }^{1}$, J. R. Molina ${ }^{2}$, M. Forsberg ${ }^{3}$, H. Kindahl ${ }^{4}$ and L.-E. Edqvist ${ }^{3}$
}

${ }^{1}$ Posgrado Regional en Ciencias Veterinarias Tropicales (PCVET), ${ }^{2}$ Universidad Nacional, Heredia, Costa Rica, Facultad de Agronomía, Universidad de Costa Rica, San José, Costa Rica, and ${ }^{3}$ Departments of Clinical Chemistry, and ${ }^{4}$ Obstetrics and Gynaecology, Faculty of Veterinary Medicine, Swedish University of Agricultural Sciences.

\begin{abstract}
Toribio, R. E., J. R. Molina, M. Forsberg, H. Kindahl and L.-E. Edqvist: Effects of calf removal at parturition on postpartum ovarian activity in zebu (Bos indicus) cows in the humid tropics. Acta vet. scand. 1995, 36, 343-352. - To assess endocrine and morphological responses of ovaries to total weaning at parturition, $6 \mathrm{Zebu}$ (Bos indicus) cows 5 years or older were investigated. Following parturition, blood samples were collected daily during the first month and twice weekly thereafter until day 60 to determine concentrations of progesterone $\left(\mathrm{P}_{4}\right)$ and prostaglandin $\mathrm{F}_{2 \alpha}$ metabolite.

It took between 25 to 32 days to complete uterine involution.The prostaglandin metabolite remained elevated for a mean period of 14.2 days (range, 4-21) postpartum. Five of the animals resumed cyclicity with a short estrous cycle starting between days 7 to 34 and lasting between 7 and 14 days. No estrous behavior was recorded prior to the short estrous cycles, but subsequent normal-length estrous cycles were all preceded by signs of estrus. In the 1 animal that resumed cyclicity with an estrous cycle of normal length on day 37 (length 20 days), the cycle was preceded by estrous behavior.

Progesterone concentrations reached a mean maximum of $4.8 \mathrm{nmol} \mathrm{liter}^{-1}$ during the short estrous cycles, and prostaglandin metabolite concentrations peaked while $\mathrm{P}_{4}$ concentrations were decreasing. $\mathrm{P}_{4}$ concentrations reached a mean maximum of 12.2 nmol liter ${ }^{-1}$ during the estrous cycles of normal length. The interval from parturition to the first estrous cycle of normal length varied between 16 and 48 days, and the length of the cycle was 18 to 22 days.

Starting 2 days postpartum, ovaries from 5 of the cows were scanned by ultrasonography every second day until day 30 postpartum. Medium-sized follicles were detected between days 4 to 7 postpartum in 4 of the scanned cows that later had short estrous cycles. The time between parturition and the appearance of the first dominant follicle was 7.6 days (range 6-10 days). The interval between parturition and the appearance of the first ovulatory-sized follicle was 10.2 days (range 8-13 days). In 3 of the scanned cows this ovulatory-sized follicle ovulated.

We conclude that cyclic ovarian activity in Zebu cows can start early in the postpartum period in the absence of offspring, and that short luteal phases, not preceded by estrous behavior, may play an important role in establishing normal postpartum ovarian activity.
\end{abstract}

progesterone; prostaglandin.

\footnotetext{
${ }^{1}$ Present address: R.E. Toribio, P.O. Box 1776, Colón, Panamá.
} 


\section{Introduction}

The long interval from parturition to the resumption of ovarian activity is a major obstacle to the improvement of reproductive efficiency, and thus to enhanced productivity, in Zebu cows reared under tropical conditions (Casida 1971, Short et al. 1990, Williams 1990). Factors known to delay the postpartum resumption of ovarian activity in domestic animals include poor nutrition (Dunn \& Kaltenbach 1980, Olivares et al. 1981), advanced age (Laster et al. 1973) and lactation/suckling (Clapp 1937; Wiltbank \& Cook 1958; Oxenreider 1968$)$.

The suckling stimulus is considered to be one of the most important factors in delaying the onset of the first postpartum estrus in beef cows (Oxenreider \& Wagner 1971). Furthermore, an unbalanced dietary energy intake and poor body condition can enhance the inhibitory effect of suckling on ovarian activity (Randel 1990).

Short et al. (1972), who compared the length of the postpartum anestrous interval in suckled, nonsuckled, and mastectomized beef cows, concluded that suckling and the presence of mammary tissue in the absence of suckling could delay the onset of postpartum estrus regardless of lactational energy demands.

Recent experiments have shown that neither thermal, electrical nor mechanical stimulation of the teats of intact cows can activate neuronal pathways capable of inhibiting the pulsatile secretion of luteinizing hormone $(\mathrm{LH})$ (Williams et al. 1984, Cutshaw et al. 1992). In cows whose teats and udder had been masked (McVey \& Williams 1991) or surgically removed (Viker et al. 1989), the mammary somatosensory pathways did not appear to be involved in the transmission of signals that regulate $\mathrm{LH}$ pulsatility. It is possible that the maternal-offspring interaction is necessary for the expression of suckling-mediated anovulation and anestrus, and that these interactions are more complex than activation of neuronal pathways of the mammary gland per se.

The follicular growth pattern during the immediate postpartum period is not well understood. However, by using ultrasound scanning techniques it is possible to assess follicular activity and follow the individual and sequential patterns of development and regression during the subsequent resumption of estrous cyclicity (Pierson \& Ginther 1988, Sirois \& Fortune 1988, Murphy et al. 1990, Savio et al. 1990a).

The aim of the present study was to determine how removal of the calf at parturition affects ovarian morphological changes and secretory patterns of progesterone $\left(\mathrm{P}_{4}\right)$ and prostaglan$\operatorname{din} \mathrm{F}_{2 \alpha}$ metabolite in multiparous Zebu cows.

\section{Materials and methods}

\section{Experimental animals}

The study was undertaken at the Instituto Tecnológico de Costa Rica, San Carlos, Alajuela, situated at $9^{\circ} 22^{\prime} \mathrm{N}$ and $84^{\circ} 33^{\prime} \mathrm{W}$ and at an altitude of $75 \mathrm{~m}$. During the experiment, the annual rainfall was $3100 \mathrm{~mm}$; the mean relative humidity was $82.5 \%$ (range 66.0 98.0 ), and the average temperature was $25.7^{\circ} \mathrm{C}$ (range 16.2-35.0). Six adult Zebu cows 5 years or older were used. The animals grazed on African star grass pastures (Cynodon nlenfluensis), gamalote (Paspalum fasciculatum), pará (Brachiaria mutica) and native pastures (Axonopus compressus and Paspalum notatum). Cows were observed twice daily until parturition. All cows had spontaneous, unassisted deliveries at the expected time. Immediately after birth the calves were removed from the mothers to avoid suckling and other potential contacts with the dam. Colostrum was administered artificially. One cow delivered a still-born calf. 


\section{Blood sampling}

Blood samples for determination of $\mathrm{P}_{4}$ and prostaglandin metabolite concentrations were obtained from the jugular vein. Following parturition, blood samples were collected daily during the first month and twice weekly thereafter until day 60. The blood was collected into heparinized Monoject ${ }^{\circledR}$ tubes (Sherwood Medicals, St. Louis, MO, USA), immediately centrifuged and stored at $-20^{\circ} \mathrm{C}$ or below until analysis.

\section{Hormone analysis}

Plasma samples were analyzed for 15-keto13,14-dihydro- $\mathrm{PGF}_{2 \alpha}$ as described previously (Kindahl, et al. 1976b, Granström \& Kindahl 1982). The lower limit of detection of the assay was 75 pmol liter $^{-1}$ for a $200-\mu$ l plasma sample. The inter-assay coefficient of variation was $14 \%$ (114 pmol liter-1 ${ }^{-1}$, and the intraassay coefficients of variation varied between 6.6 and $11.7 \%$ at different ranges of the standard curve.

Progesterone concentrations were determined using the Coat-A-Count ${ }^{\circledR}$ procedure (Diagnostic Products Corporation, Los Angeles, CA, USA) (Kubasik et al. 1984). The sensitivity of the assay was $0.3 \mathrm{nmol}$ liter $^{-1}$. Intra- and inter-assay coefficients of variation were $3.2 \%$ and $11.4 \%$, respectively.

\section{Ultrasound}

The ovaries of 5 of the cows were scanned every 2 days between days 2 and 30 after calving, using a linear array ultrasound scanner equipped with a 5-MHz rectal probe (Aloka Co., Japan).

Follicles were classified according to Savio et al. 1990a and Dimmick et al. 1991.

Medium-size follicle: a follicle between 5-9 $\mathrm{mm}$ in diameter.

Dominant follicle: a follicle larger than $10 \mathrm{~mm}$ in diameter.
Ovulatory-size follicle: a follicle with a diameter $\geq 14 \mathrm{~mm}$.

Regressing follicle: a follicle that decreased in size after reaching its maximum diameter.

Ovulation was considered to have occurred when a corpus luteum (CL) could be detected in the position previously occupied by a dominant or ovulatory follicle (Murphy et al. 1990).

\section{Uterine involution}

The animals were examined by rectal palpation once a week during the first 2 weeks postpartum and then twice a week until uterine involution was completed. The criteria used for assessing completion of uterine involution were (1) return of the uterus to a normal location in the pelvic cavity, (2) normal uterine horns of approximately equal size, and (3) normal uterine tone and consistency (Morrow et al. 1969).

\section{Estrus detection}

To detect estrus, the animals were observed twice daily for $1 \mathrm{~h}$. The occurrence of vaginal bleeding and discharge, behavior of the teaser bull (penis deviated) kept together with the cows and rectal palpation of ovaries were used to determine estrus. In this study normal and short estrous cycles were defined as cycles with estrous intervals of 18-24 and 17 days or less, respectively (Murphy et al. 1990).

\section{Statistics}

The duration of the elevated levels of prostaglandin metabolite in the experiment was calculated based on the lowest postpartum levels of prostaglandin metabolite (mean+3SD; Madej et al. 1984). Elevations in concentrations of $\mathrm{P}_{4}$ in each individual animal were arbitrarily defined as values above the mean+3SD of the concentrations measured 
Table 1. Cyclic activity and uterine involution after parturition (days).

\begin{tabular}{lccccc}
\hline Cow No. & $\begin{array}{c}\text { Interval parturition } \\
\text { first short cycle }\end{array}$ & $\begin{array}{c}\text { Length of the first } \\
\text { short cycle }\end{array}$ & $\begin{array}{c}\text { Interval parturition } \\
\text { first normal cycle }\end{array}$ & $\begin{array}{c}\text { Length of the first } \\
\text { normal cycle }\end{array}$ & $\begin{array}{c}\text { Uterine } \\
\text { involution }\end{array}$ \\
\hline 36 & 14 & 10 & 25 & 21 & 31 \\
75 & 11 & 10 & 25 & 22 & 25 \\
301 & 12 & 8 & 33 & 20 & 32 \\
349 & 7 & 7 & 16 & 20 & 25 \\
396 & - & - & 37 & 21 & 26 \\
1106 & 34 & 14 & 48 & 20.3 & 30 \\
Mean & 15.6 & 9.8 & & & 28.2 \\
\hline
\end{tabular}

during the first 6 days after parturition. The length of the lutal phase was measured as the time between the first elevation of $\mathrm{P}_{4}$ and the point at which it returned to the baseline again.

\section{Results}

During the experimental period, none of the animals had any health problems. It took between 25 and 32 days to complete uterine involution. The average duration of elevated prostaglandin metabolite concentrations in blood postpartum was 14.2 days (range 4-21 days).

In 4 animals ovarian activity started with a short estrous cycle followed by a cycle of normal length (Fig. 1a-b, 2b and 3b). In 1 animal, the first cycle of normal length was preceded by 2 short cycles (Fig. 2a). Only 1 animal began estrous cyclicity with a cycle of normal length (Fig. 3a). The mean maximum $\mathrm{P}_{4}$ concentration was $4.8 \mathrm{nmol} \mathrm{liter}^{-1}$ (range 2.8-7.0



DAYS POSTPARTUM

Figures 1a-b. Patterns of progesterone $\left(\mathrm{P}_{4}\right), \mathrm{PGF}_{2 \alpha}$ metabolite (PGF), and follicular development (upper panel) in cows No. 36 and No. 75 during the first 60 days of the postpartum period. The calf was removed after parturition and blood samples were collected daily for the first 30 days and twice weekly thereafter. 


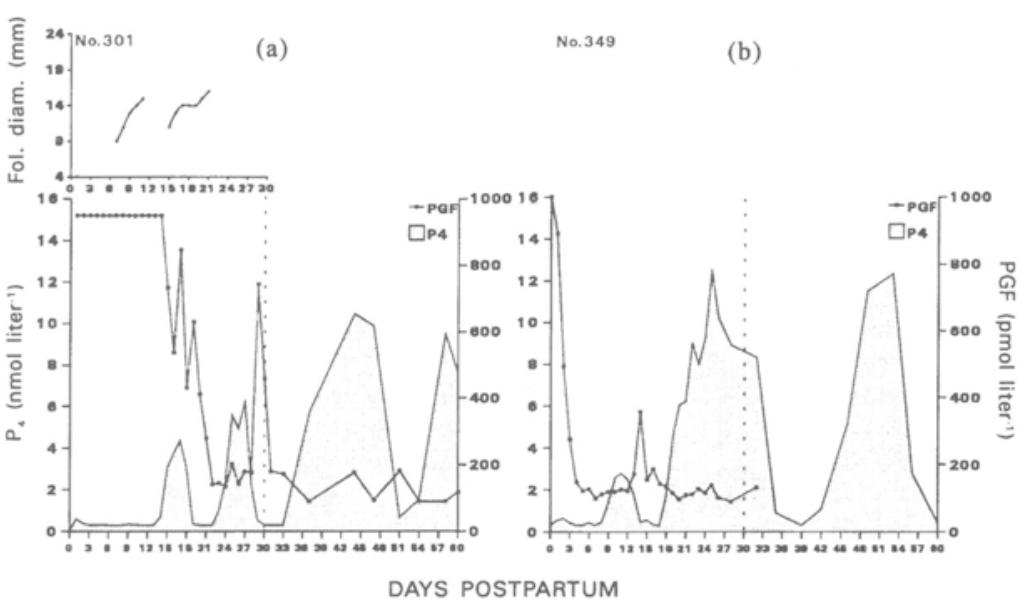

Figures 2a-b. Patterns of progesterone $\left(\mathrm{P}_{4}\right), \mathrm{PGF}_{2 \alpha}$ metabolite (PGF) in cows 301 and 349 and follicular development in cow 301 (upper panel) during the first 60 days of the postpartum period. Blood samples were collected daily for the first 30 days and twice weekly thereafter. The calf was removed after parturition.

nmol liter ${ }^{-1}$ ) during the short cycle and 12.2 nmol liter-1 (range 10.5-15.0 nmol liter ${ }^{-1}$ ) during the first cycle of normal length. The mean $\mathrm{P}_{4}$ concentration on day 5 of the short cycle was half of that recorded on day 5 of the cycle of normal length. In animals with short estrous cycles, the first elevation in $\mathrm{P}_{4}$ appeared between days 7 and 34, and the cycle length varied between 7 and 14 days (Table 1). In the 4 animals with 1 short cycle, the termination of $\mathrm{P}_{4}$ secretion during the short luteal phase was associated with $\mathrm{PGF}_{2 \alpha}$ release. In the animal with 2 short cycles, the end of the first short luteal phase coincided with postpartum release of $\mathrm{PGF}_{2 \alpha}$ and the decline of $\mathrm{P}_{4}$ in the second cycle coincided with a peak of PGF (Fig 2a). None of the animals showed standing estrus prior to the short cycle.

Estrous cycles of normal length started between days 16 and 48, and elevated $\mathrm{P}_{4}$ concentrations were recorded between 18 and 22 days (Table 1). All animals showed signs of estrus prior to the first cycle of normal length.
In 3 of the animals, ovulations, confirmed by ultrasound examination, occurred prior to the first short cycle (Figs. 1a-b and 2a). In the 4 scanned cows with short cycles, medium-sized follicles were detected within the first week postpartum (range 4-7 days). The interval between parturition and the appearance of the first dominant follicle was 7.6 days (range 6-10 days), and the time elapsed between parturition and the first observation of an ovulatory-size follicle was 10.2 days (range 8-13 days). In 3 of 5 cows, the first dominant follicle ovulated.

One animal seemed to have had a short period of luteal activity between days 12 and 16 postpartum, as indicated by a slight increase in $\mathrm{P}_{4}\left(2.0 \mathrm{nmol} \mathrm{liter}^{-1}\right)$ and a subsequent elevation in prostaglandin metabolite levels (Fig. $3 b)$. Ultrasonography revealed a mediumsized follicle $(7 \mathrm{~mm})$ on day 4 postpartum, which had reached ovulatory size by day 8 , just before the increase in progesterone. The follicle did not ovulate and regressed. An- 


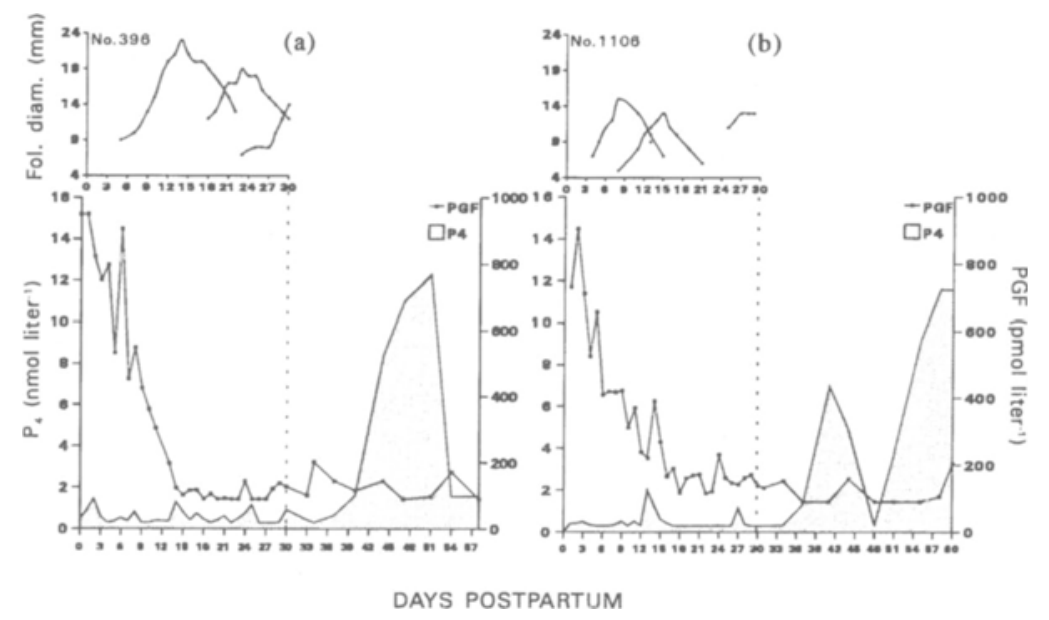

Figures 3a-b. Patterns of progesterone $\left(\mathrm{P}_{4}\right), \mathrm{PGF}_{2 \alpha}$ metabolite (PGF), and follicular development (upper panel) in cows 396 and 1106 during the first 60 days of the postpartum period. The calf was removed after parturition and blood samples were collected daily for the first 30 days and twice weekly thereafter.

other follicle appeared on day 8 and reached maximum size on day $15(13 \mathrm{~mm})$ after which it started to regress.

In 1 cow (Fig. 3a), $\mathrm{P}_{4}$ concentrations remained low until day 40 after parturition when the animal ovulated and had a normal-length estrous cycle. $\mathrm{P}_{4}$ reached a maximum value of 12.9 nmol liter ${ }^{-1}$. Ultrasonography showed follicular growth and regression during the first 30 days postpartum. The first dominant follicle appeared on day 6 and reached maximum size on day $14(23 \mathrm{~mm})$ after which it regressed. A second follicle reached dominant size on day 17 and maximum size on day 23 $(19 \mathrm{~mm})$, whereupon it regressed. A third follicle was present on day 23 and reached dominant size on day 28. Ovulation, as determined by rectal palpation and analysis of the $\mathrm{P}_{4}$ profile, occurred on day 37 .

\section{Discussion}

The most important finding in this study was that under tropical conditions Zebu cows are capable of resuming cyclic ovarian activity at an early stage postpartum in the absence of offspring, in contrast to suckled Zebu cows (Mukasa-Mugerwa et al. 1991, Tegegne et al. 1993). Furthermore, short luteal phases not preceded by estrous behavior were detected and probably played an important role in establishing normal postpartum ovarian activity. The Zebu cows in this study resumed follicular development soon after calving, as is also the case in dairy cows (Savio et al. 1990a). Like Murphy et al. (1990), we observed that medium-sized and dominant follicles appeared early in the postpartum period, and several were capable of ovulating once the maternal bond (calf) had been removed. In beef cattle Murphy et al. (1990) observed that before ovulation there were recurrent periods of growth and regression of dominant follicles. In these cases, follicles failed to ovulate and, consequently, underwent atresia. Even though 3 out of 5 cows in this study ovulated, a similar pattern was observed. Like Dimmick 
et al. (1991), we observed a decrease in the follicular antrum diameter preceding the $\mathrm{P}_{4}$ concentration increase, which might have been caused by follicular luteinization.

In 4 of the animals, the short cycle was followed by an estrous cycle of normal length. These results agree with previous reports in cattle and sheep (Lamming et al. 1981, Ramirez-Godinez et al. 1982; Madej et al. 1986, Southee et al. 1988) and suggest that short estrous cycles may be of physiological importance in the postpartum period. It has been reported that a great proportion of Zebu cows ovulate during the postpartum period without showing estrous behavior which was also verified in this study (Dawuda et al. 1989, Mukasa-Mugerwa et al. 1991; Tegegne et al. 1993). Ramirez-Godinez et al. (1982) concluded that $\mathrm{P}_{4}$ concentrations can increase prior to the first normal postpartum estrus. Thus short cycles in Zebu cows should not be considered as an ovarian disorder as suggested by Eger et al. (1988) for dairy cattle.

Calf removal and the consequent obliteration of suckling stimuli could influence the release of gonadotropins, resulting in the resumption of cyclicity. A small increase in plasma $\mathrm{P}_{4}$ concentrations potentiates the frequency of $\mathrm{LH}$ and FSH pulses following weaning of beef cows after parturition (Williams et al. 1983). During the normal-length estrous cycle, $\mathrm{PGF}_{2 \alpha}$ is spontaneously secreted once the uterus has been under progestational influence for 10-14 days (Silvia et al. 1991). This time span could depend on the time needed to accumulate precursors and releasing factors of $\mathrm{PGF}_{2 \alpha}$ at the endometrial level, but the early activation of this system is not clearly understood (Cooper et al. 1991). The occurrence of short estrous cycles with progesterone concentrations lower than those in normal cycles could be related to an imbalance of the hypophyseal-pituitary axis, rendering the system incapable of maintaining luteotropic support, or to the presence of luteolytic factors (Schams et al. 1978). Savio et al. (1990b) proposed that carry-over effects of progesterone from the previous pregnancy in the early post-partum period could explain the occurrence of short estrous cycles. Copelin et al. (1987) reported that short-lived corpora lutea do not have inherently short life spans. Rather, the presence of the uterus results in premature luteolysis. Hysterectomized cows always show a persistent luteal phase after the first ovulation postpartum, and no short estrous cycles occur since the luteolytic mechanism is removed with the uterus (Lindell et al. 1982). Copelin et al. (1989) showed that active immunization of beef cows against $\mathrm{PGF}_{2 \alpha}$ pre- and postpartum prevented the development of corpora lutea with short life spans, and they concluded that a premature release of $\mathrm{PGF}_{2 \alpha}$ from the uterus was responsible for the short estrous cycles in beef cows. It seems that the mechanism to synthetize and release $\mathrm{PGF}_{2 \alpha}$ of the uterus is not controlled and that the uterus is producing and releasing $\mathrm{PGF}_{2 \alpha}$ in response to increased concentrations of $\mathrm{P}_{4}$; and thus the short cycle is obtained (Edqvist et al. 1984).

In the present study, prostaglandin metabolite levels were elevated in all cows at parturition and remained high for approximately 2 weeks, which is in agreement with previous reports for Zebu cattle (Toribio et al. 1994). The luteolytic $\mathrm{PGF}_{2 \alpha}$ release was clearly observed in 4 of 6 animals after the $\mathrm{P}_{4}$ decrease in the short estrous cycles. In the animal having two consecutive short estrous cycles, the first cycle was terminated in connection with a massive postpartum $\mathrm{PGF}_{2 \alpha}$ release, and the second short cycle was terminated by a surge release of prostaglandin. Further investigations are needed to determine whether the oc- 
currence of 2 consecutive short estrous cycles could be due to the first one coinciding with the massive postpartum release of $\mathrm{PGF}_{2 \alpha}$. The short estrous cycles observed in this study lasted 7-10 days which agrees well with the concept that the CL cannot be lysed by prostaglandin during its first 5 days (Hansel \& Convey 1983), and the regression of the CL is usually completed within $48 \mathrm{~h}$ after the onset of the $\mathrm{PGF}_{2 \alpha}$ release (Kindahl et al. 1976a).

\section{Acknowledgements}

The authors are indebted to the Swedish Agency for Research Cooperation with Developing Countries (SAREC), for the grant supporting this study, and to the Instituto Tecnológico de Costa Rica for providing the farm facilities. Financial support for Ramiro E. Toribio from the Deutscher Akademischer Austauschdienst (DAAD) is also gratefully acknowledged. Thanks are due to Dr. Jorge Mario Bolaños for showing special interest in our work and for good collaboration. We want to express our sincere gratitude to Drs. Eduard Müller, Carlos Galina, Ron Dwinger, Enrique Pérez and Ana María Ortuño for revising earlier drafts. Dr. Gary Williams also provided valuable comments on the manuscript.

\section{References}

Casida $L E$ : The postpartum interval and its relation to fertility in the cow, sow and ewe. J. Anim. Sci. (Suppl. 1). 1971, 32, 66-72.

Clapp H: A factor in breeding efficiency of dairy cattle. Proc. Amer. Soc. Anim. Prod. 1937, 37, 259-265.

Cooper DA, Carver DA, Villeneuve P, Silvia WJ, Inskeep EK: Effects of progestagen treatment on concentrations of prostaglandins and oxytocin in plasma from the posterior vena cava of post-partum beef cows. J. Reprod. Fertil. 1991, 91, 411421.

Copelin JP, Smith MF, Garverick HA, Youngquist $R S$ : Effect of uterus on subnormal luteal function in anoestrus beef cows. J. Anim. Sci. 1987, 64, 1505-1511.

Copelin JP, Smith MF, Keisler DH, Garverick HA: Effect of active immunization of pre-partum and post-partum cows against prostaglandin $\mathrm{F}_{2 \alpha}$ on lifespan and progesterone secretion of short- lived corpora lutea. J. Reprod. Fert. 1989, 87, 199-207

Cutshaw JL, Hunter JF, Williams GL: Effects of transcutaneous thermal and electrical stimulation of the teat on pituitary luteinizing hormone, prolactin and oxytocin secretion in ovariectomized, estradiol-treated beef cows following acute weaning. Theriogenology 1992, 37, 915934.

Dawuda PM, Eduvie LO, Esievo KAN, Molokwu ECI: Silent oestrus manifestation in Nigerian Bunaji Zebu cows. Anim. Reprod. Sci. 1989, 21, 79-85.

Dimmick MA, Gimenez T, Spitzer JC: Ovarian endocrine activity and development of ovarian follicles during the postpartum interval in beef cows. Anim. Reprod. Sci. 1991, 24, 173-183.

Dunn TG, Kaltenbach CC: Nutrition and the postpartum interval of the ewe, sow and cow. J. Anim. Sci. (Suppl. 2) 1980, 51, 29.

Edqvist L-E, Fredriksson G, Kindahl H, Larsson $K$, Madej A: Short oestrous cycles post partum in cattle. In: The use of nuclear techniques to improve domestic buffalo production in ASIA. Proceedings of the final research co-ordination meeting Manilla, 30 January - 3 February 1984. IAEA, Vienna. 79-83.

Eger S, Shemesh M, Schindler H, Amir S, Foote RH: Characterization of short luteal cycles in the early postpartum period and their relation to reproductive performance of dairy cows. Anim. Reprod. Sci. 1988, 16, 215-224.

Granström E, Kindahl H: Radioimmunoassay of the major plasma metabolite of $\mathrm{PGF}_{2 \alpha}, 15$-keto13,14-dihydro-PGF ${ }_{2 \alpha}$. Methods Enzymol. 1982, 86, 320-339.

Hansel W, Convey EM: Physiology of the estrous cycle. J. Anim. Sci. 1983, 57, (Suppl. 2) 404-424.

Kindahl H, Edqvist L-E, Bane A, Granström E: Blood levels of progesterone and 15-keto-13,14dihydroprostaglandin $\mathrm{F}_{2 \alpha}$ during the normal oestrous cycle and early pregnancy in heifers. Acta endocr. 1976a, 82, 134-149.

Kindahl H, Edqvist L-E, Granström E, Bane A: The release of prostaglandin $\mathrm{F}_{2 \alpha}$ as reflected by 15 keto-13,14-dihydroprostaglandin $F_{2 \alpha}$ in the peripheral circulation during normal luteolysis in heifers. Prostaglandins 1976b, 11, 871-878.

Kubasik NP, Hallauer GD, Brodows RG: Evaluation of a direct solid-phase radioimmunoassay for progesterone, useful for monitoring luteal function. Clin. Chem. 1984, 30, 284-286. 
Lamming GE, Wathes DC, Peters AR: Endocrine patterns of the post-partum cow. J. Reprod. Fert. (Suppl. 30) 1981, 155-170.

Laster DB, Glimp HA, Gregory KE: Effects of early weaning on postpartum reproduction of cows. $\mathbf{J}$. Anim. Sci. 1973, 36, 734.

Lindell J-O, Kindahl H, Edqvist L-E, Tufvesson G: Effect of hysterectomy on the postpartum prostaglandin levels in the cow. Acta vet. scand. 1982, 23, 144-146.

Madej A, Kindahl H, Woyno W, Edqvist L-E, Stupnicki $R$ : Blood levels of 15-keto-13,14-dihydroprostaglandin $\mathrm{F}_{2 \alpha}$ during the postpartum period in primiparous cows. Theriogenology 1984, 21, 279-287.

Madej A, Kindahl H, Larsson K, Edqvist L-E: Sequential hormonal changes in the postpartum dairy cow. Acta vet. scand. 1986, 27, 280-295.

McVey WR Williams GL: Mechanical masking of neurosensory pathways at the calf-teat interface: endocrine, reproductive and lactational features of the suckled cow. Theriogenology 1991, 35, 931-941.

Morrow DA, Roberts SJ, McEntee K: A review of postpartum ovarian activity and involution of the uterus and cervix in cattle. Cornell Veterinarian 1969, 59, 134-154.

Mukasa-Mugerwa E, Tegegne A, Ketema H: Patterns of postpartum oestrus onset and associated plasma progesterone profiles in Bos indicus in Ethiopia. Anim. Reprod. Sci. 1991, 24, 73-84.

Murphy MG, Boland MP, Roche JF: Pattern of follicular growth and resumption of ovarian activity in post-partum beef suckler cows. J. Reprod. Fert. 1990, 90, 523-533.

Olivares $R$, Chicco $C F$, Rodríguez $R$, Hernández $P$, Verde $O$ : Suplementación pre y post-parto en vacas Brahman de primera lactancia. (Pre- and postpartum supplementation of Brahman cows in the first lactation). VIII Reunión ALPA. 1981, Resumen R-46.

Oxenreider $S L$ : Effects of suckling and ovarian function on postpartum reproductive activity in beef cattle. Amer. J. vet. Res. 1968, 21, 2099-2102.

Oxenreider SL Wagner WC: Effect of lactation and energy intake on postpartum ovarian activity in the cow. J. Anim. Sci. 1971, 33, 1026.

Pierson RA, Ginther OJ: Ultrasonic imaging of the ovaries and uterus in cattle. Theriogenology 1988, 29, 21-37

Ramirez-Godinez JA, Kiracofe GH, Schalles RR, Niswender $G D$ : Endocrine patterns in the post- partum beef cow associated with weaning: a comparison of the short and subsequent normal cycles. J. Anim. Sci. 1982, 55, 153-158.

Randel RD: Nutrition and postpartum rebreeding in cattle. J. Anim. Sci. 1990, 68, 853-862.

Savio JD, Boland M, Hynes N, Roche JF: Resumption of follicular activity in the early post-partum period of dairy cows. J. Reprod. Fert. 1990a, 88, 569-579.

Savio JD, Boland MP, Roche JF: Development of dominant follicles and length of ovarian cycles in post-partum dairy cows. J. Reprod. Fert. 1990b, 88, 581-591.

Schams D, Schallenberger E, Menzer CH, Stangl J, Zottmeier K, Hoffmann B, Karg H: Profiles of $\mathrm{LH}, \mathrm{FSH}$ and progesterone in postpartum dairy cows and their relationship to the commencement of cyclic functions. Theriogenology 1978, 10, 453-463.

Short RE, Bellows RA, Moody EL, Howland BE: Effects of suckling and mastectomy on bovine postpartum reproduction. J. Anim. Sci. 1972, 34, 70-74.

Short RE, Bellows RA, Staigmiller RB, Berardinelli $J G$, Custer EE: Physiological mechanism controlling anestrus and infertility in postpartum beef cattle. J. Anim. Sci. 1990, 68, 799-816.

Silvia WJ, Lewis GS, McCracken JA, Thatcher WW, Wilson L: Hormonal regulation of uterine secretion of prostaglandin $\mathrm{F}_{2 \alpha}$ during luteolysis in ruminants. Biol. Reprod. 1991, 45, 655-663.

Sirois J, Fortune JE: Ovarian follicular dynamics during the estrous cycle in heifers monitored by real-time ultrasonography. Biol. Reprod. 1988, 39, 308-317.

Southee JA, Hunter MG, Law AS, Haresign W: Effect of hysterectomy on the short life-cycle corpus luteum produced after GnRH-induced ovulation in the anoestrus ewe. J. Reprod. Fert. $1988,84,149-155$.

Tegegne A, Geleto A, Kassa T: Short luteal phases and ovulations without oestrus in primiparous Borana (Bos indicus) cows in the central highlands of Ethiopia. Anim. Reprod. Sci. 1993, 31, 21-31.

Toribio RE, Molina JR, Bolaños JM, Kindahl H: Blood levels of the prostaglandin $\mathrm{F}_{2 \alpha}$ metabolite during the postpartum period in Bos indicus cows in the humid tropics. J. Vet. Med. A. 1994, 41, 630-639.

Viker SD, McGuire WJ, Wright JM, Beeman KB, Kiracofe $G H$ : Cow-calf association delays post- 
partum ovulation in mastectomized cows. Theriogenology 1989, 32, 467-474.

Williams GL: Suckling as a regulator of postpartum rebreeding in cattle: a review. J. Anim. Sci. 1990, $68,831-852$.

Williams GL, Kirsch JD, Post GR, Tilton JE, Slanger $W D$ : Evidence against chronic teat stimulation as an autonomous effector of diminished gonadotropin release in beef cows. J. Anim. Sci. 1984, 59, 1060-1069.

Williams GL, Talavera F, Petersen BJ, Kirsch JD, Tilton JE: Coincident secretion of follicle-stimulating hormone and luteinizing hormone early postpartum beef cows: Effects of suckling and low-level increases of systemic progesterone. Biol. Reprod. 1983, 29, 362-373.

Wiltbank JN, Cook A: The comparative reproductive performance of nursed milked cows. J. Anim. Sci. 1958, 17, 640-648.

\section{Sammanfattning}

Inverkan av avvänjning direkt efter förlossningen på äggstocksaktiviteten hos zebukor

På 6 zebukor studerades de perifera plasmanivåerna av 15-ketodihydro-PGF $\mathrm{PG}_{2 \alpha}$ och progesteron efter förlossningen. Hormonmätning gjordes fortlöpande under 60 dagar efter förlossningen. Blodprover samlades dagligen under de första 30 dagarna och därefter 2 gånger per vecka. Äggstockarna undersöktes också med ultraljud de första 30 dagarna. Två gånger per dag gjordes observationer i närvaro av tjur för att konstatera brunst. Livmoderinvolutionen tog mellan 25 och 32 dagar. Frisättningen av prostaglandin $F_{2 \alpha}$ post partum varade mellan 4 - 21 dagar. Hos 5 av korna kunde en första kort lutealfas, med en längd mellan 7 - 4 dagar, registreras mellan dag 7 och 34. Endast ett djur hade en första lutealfas med normal längd (20 dagar) från dag 37 . Inget av djuren visade brunst i samband med den korta lutealfasen men 3 av djuren hade ägglossning. Alla visade däremot brunst vid lutealfaser av normal längd. De maximala progesteronkoncentrationerna i plasma var under den korta lutealfasen $4.8 \mathrm{nmol} / \mathrm{l}$ och under den normala $12.2 \mathrm{nmol} / \mathrm{l}$.

Undersökningen visade att zebukor utan diande kalv kan återuppta normal äggstocksaktivitet kort efter förlossningen och att korta lutalfaser kan ha betydelse för en normalisering av äggstocksfunktionen.

(Received January 30, 1995; accepted May 24, 1995).

Reprints may be obtained from: Dr. J. R. Molina, Univercidad Nacional, Heredia, Costa Rica. 